\title{
New Product Success: Is It Really Controllable by Managers in Highly Turbulent Environments?
}

\author{
Cornelia Droge, Roger Calantone, and Nukhet Harmancioglu
}

\begin{abstract}
This research proposes and tests a model of direct and indirect effects linking four antecedents to new product success: (1) a proactive strategic orientation along with enabling (2) organic organizational structures should lead to more (3) innovativeness and (4) market intelligence. Innovativeness and market intelligence should in turn lead to greater new product success. The relationships among the four antecedents are not hypothesized to be moderated by environmental turbulence because their domain is intraorganizational. However, the relationships from intraorganizational constructs to new product success are hypothesized to be moderated by environmental turbulence because success depends in part on the environment in which the new product must compete. The model was tested using a sample composed of 202 small business units of manufacturers on the Fortune 500. The sample was heavily involved in new product development: Their average annual research and development budget was $\$ 360.4$ million, and approximately $8.2 \%$ of sales came from products introduced in the last five years. A two-group structural equation model analysis supports the moderation model overall and reveals the pattern of direct, indirect, and total effects. The results show that innovativeness (but not market intelligence) directly predicts new product success when turbulence is high, whereas market intelligence (but not innovativeness) directly engenders new product success in low turbulence. Environmental turbulence also affects the total indirect impact of strategy proactiveness and organizational organicity on new product success. These indirect effects operate through innovativeness and market intelligence as complete mediators.
\end{abstract}

\section{Introduction}

$\mathrm{T}$ he key to maintaining long-term competitive position is to repeatedly commercialize successful new products (Griffin and Page, 1996). However, escalating research and development (R\&D) costs, rapid and radical technological developments, short product life cycles, intense competition, and high new product failure rates make new product development (NPD) high risk and difficult

Address correspondence to: Cornelia Droge, Department of Marketing and Supply Chain Management, Eli Broad College of Business, Michigan State University, N307 Business Complex, East Lansing, MI 48824. Tel.: (517) 353-6381. E-mail: droge@msu.edu.
(Calantone and Di Benedetto, 1988; Rindfleisch and Moorman, 2001; Song, Thieme, and Xie, 1998). Because these turbulent, hostile environments make NPD both more important and more difficult, there is a rich stream of literature focusing on the determinants of new product success.

Research has scrutinized how firms can achieve competitive advantage through intraorganizational factors - that is, factors controllable by management (Day, 1994; Di Benedetto, 1999; Montoya-Weiss and Calantone, 1994). This research examines proactive strategic orientation, which is characterized by aggressive firm strategies and bold actions, and organizational structure, which concerns the allocation of work 
roles and administrative mechanisms for the coordination and control of activities and resource flows (Atuahene-Gima and Ko, 2001; Gatignon and Xuereb, 1997; Matsuno, Mentzer, and Ozsomer, 2002). Aggressive, proactive strategies and organic, fluid structures are often recommended for success in product development (Calantone, Di Benedetto, and Bhoovaraghavan, 1994; Day, 1994; Li and Calantone, 1998; Moorman, 1995); however, it is proposed that these effects are not direct. Instead, a proactive strategic orientation and an organic organizational structure lead indirectly to NPD success through market intelligence and innovativeness (Figure 1). Market intelligence and innovativeness are hypothesized to be complete (not partial) mediators. These mediators were chosen because, as Cooper (1979) originally stated, a product's success originates in two processes: (1) information acquisition, for which market intelligence is a proxy; and (2) proficiency of the NPD process, which the present study captures in innovativeness. Thus, this study's first major goal is to unravel direct and indirect effects of model constructs on new product success (i.e., to examine complete versus partial mediation).

The second goal is to examine the role of environmental turbulence. Turbulent, hostile environments are characterized by intense competition, frequent technological advancements, and changes in customer preferences; they are major contributors to new

\section{BIOGRAPHICAL SKETCHES}

Dr. Cornelia Droge is professor of marketing in the Department of Marketing and Supply Chain Management in the Eli Broad Graduate School of Management at Michigan State University. She earned her Ph.D. and M.B.A. from McGill University in Montreal, Canada. Her research interests focus on satisfaction/loyalty, new products, and strategic marketing (especially topics related to the interface of marketing, supply chain, and operations).

Dr. Roger Calantone, NPDP, is the Eli Broad University Professor of Business in the Eli Broad Graduate School of Management at Michigan State University. He is also adjunct professor of economics and director of the program in information technology management. His research is focused on product innovation strategy and decision making.

Dr. Nukhet Harmancioglu is assistant professor of marketing in the Faculty of Business Administration at Bilkent University in Bilkent, Ankara, Turkey. She earned her Ph. D. degree from Michigan State University in East Lansing. Her research interests span the fields of strategic marketing management, new product development, and international business. She was the recipient of the 2005 Product Development \& Management Association Dissertation Proposal Competition product failure rates as high as $50 \%$ (Di Benedetto, 1999; Rindfleisch and Moorman, 2001). Knowledge, resources, processes, or products become obsolete quickly, and it is difficult to monitor or predict customer preferences, the actions of competitors, and technological discontinuities. Superior capabilities in market intelligence gathering and innovativeness may thus be required to survive. Innovativeness and market intelligence comprise boundary-spanning activities (which sense, respond to, or alter the market), and it is proposed that specific given levels of these activities will lead to less new product success in hostile environments. In other words, environmental turbulence is a potential moderator of model relationships.

To support this study's moderation hypotheses, Day's (1994) conceptualization of boundary-spanning activities, Moorman (1995), and the market orientation and contingency theory literatures can be referenced. In these literatures, some studies have examined moderation by environmental factors of the relationship between market or firm orientation and new product outcomes (see Atuahene-Gima, 1995; Han, Kim, and Srivastava, 1998; Homburg and Pflesser, 2000; Kohli and Jaworski, 1990; Ottum and Moore, 1997). Finally, the relationships among intraorganizational constructs (i.e., non-boundaryspanning constructs) are not hypothesized to be moderated by environmental turbulence.

The article begins by presenting an overview of this contingency model and defining all model constructs. Hypotheses are developed (for direct versus indirect paths and for moderation) and are then tested using a two-group structural equation modeling (SEM). The presentation of the results is followed by a discussion of managerial and theoretical implications.

\section{Construct Definitions and Model Overview}

Construct definitions and a short overview of the model, which is depicted in Figure 1, are presented first. New product success, the dependent construct in this study's model, indicates the extent to which financial objectives were met (Atuahene-Gima, 1995; Gatignon and Xuereb, 1997; Griffin and Page, 1996; Olson, Walker, and Ruekert, 1995; Song and Parry, 1996). The four antecedents to new product success are considered intraorganizational factors under managerial control. They are defined as follows.

First, a proactive strategic orientation is characterized by a proactive and aggressive stance, bold wide- 


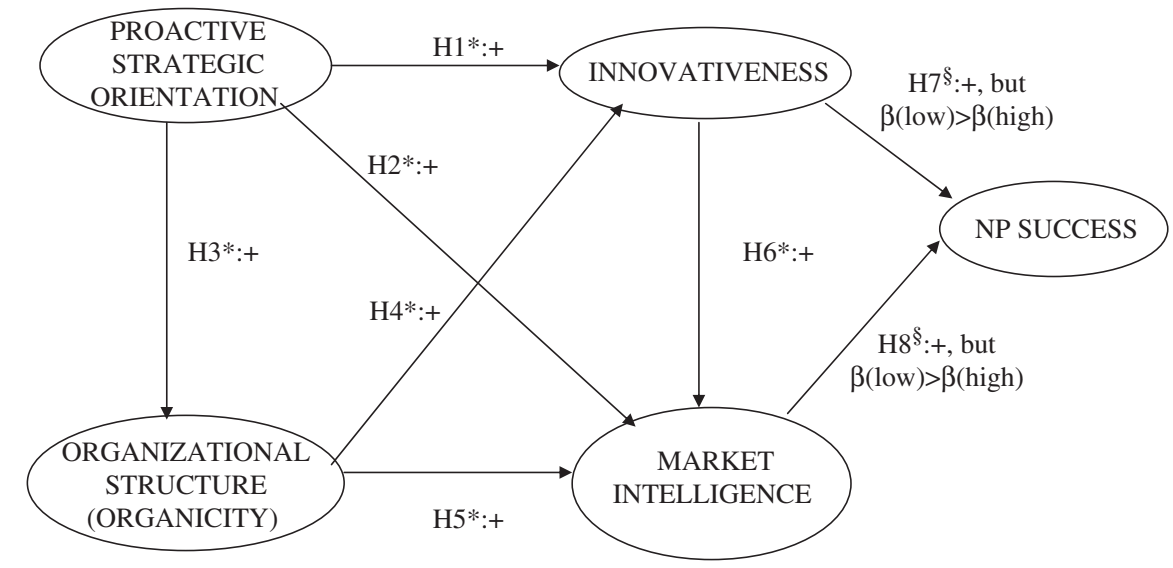

Figure 1. Model and Hypotheses.

* The relationships indicated in H1 through $\mathrm{H6}$ are not hypothesized to be moderated by environmental turbulence.

$\S$ The relationships specified in $\mathrm{H} 7$ and $\mathrm{H8}$ are hypothesized to be greater in a low turbulence environment than in an environment with high turbulence ( $\beta$ 's in low environmental turbulence will be greater than $\beta$ 's in high environmental turbulence).

ranging actions, and decision making to enhance competitiveness. Such a strategic orientation engenders a strong emphasis on technological leadership and radical product innovations and a preference for highrisk, high-potential-reward projects over safer projects (Calantone, Di Benedetto, and Bhoovaraghavan, 1994; Gatignon and Xuereb, 1997; Han, Kim, and Srivastava, 1998). This definition is comparable to Miles and Snow's (1978) prospectors and analyzers and to Miller and Friesen's (1982) entrepreneurial firms.

Second, an organizational view of innovation was adopted that characterizes innovativeness as "a means of changing an organization, whether as a response to changes in its internal or external environment or as a preemptive action taken to influence an environment" (Damanpour, 1991, p. 556). The innovativeness construct encompasses exploiting new product and market opportunities and thus focuses on actions representing discontinuity (i.e., a departure from existing practices; Brown and Eisenhardt, 1997; Calantone, Di Benedetto, and Bhoovaraghavan, 1994; Danneels and Kleinschmidt, 2001; De Brentani, 2001; Gatignon and Xuereb, 1997; Hultink et al., 1997). Innovativeness is viewed as a capability that incorporates receptivity to new ideas, products, or processes, as well as an increased likelihood of their implementation or adoption (Calantone, Garcia, and Droge, 2003; Hurley and Hult, 1998).

Third, in the new product literature, market intelligence is considered an organizational competence and a strategic asset of an organization (Calantone and Di Benedetto, 1988; Glazer, 1991; Li and Calantone, 1998; Li, Nicholls, and Roslow, 1999; Moor- man, 1995). Market intelligence is defined as a competence or capability to generate and integrate knowledge about the market.

The fourth intraorganizational construct under managerial control is organizational structure. Miller (1987, p. 8) defined structure as the "enduring allocation of work roles and administrative mechanisms that allow firms to conduct, coordinate, and control their work activities and resource flows." Organic structures are characterized by fluidity and flexibility in task execution, open channels of communication, decentralized decision making, and few formal procedures (Achrol, 1991; Olson, Walker, and Ruekert, 1995; Workman, 1993). In contrast, mechanistic structures are hierarchical, employing formalized rules and regulations, and tend to have centralized decision making (Covin and Slevin, 1989; Dewar and Dutton, 1986; Miller and Friesen, 1982).

H1 through H6 (Figure 1) concerning the paths among these four intraorganizational constructs are not hypothesized to vary due to environmental turbulence. Environmental turbulence is defined to comprise three dimensions: market turbulence, competition intensity, and rate of technological change. In contrast, the strengths of the paths from innovativeness and market intelligence to new product performance (i.e., $\mathrm{H} 7$ and $\mathrm{H} 8$ in Figure 1) will be determined in part by factors not under the control of decision makers; it is proposed that turbulence will moderate these paths. This moderation effect is supported by NPD contingency theory, which proposes that the relationships from intraorganizational factors to new product success are contingent upon environmental 
turbulence (Atuahene-Gima, 1995; Calantone, Schmidt, and Di Benedetto, 1997; Calantone, Garcia, and Droge, 2003; Han, Kim, and Srivastava, 1998; Souder and Song, 1998). The primary sources of turbulence in NPD include technological advancements and difficulties in monitoring competitor actions and customer preferences (Calantone, Garcia, and Droge, 2003; Cooper and Kleinschmidt, 1991; Moorman and Miner, 1997; Mullins and Sutherland, 1998). The next sections develop the hypotheses.

\section{Development of Hypotheses}

\section{The Effects of Proactive Strategic Orientation ( H1, H2, H3)}

Firms' strategic orientations are crucial to understanding product innovation and performance (Atuahene and Ko, 2001; Gatignon and Xuereb, 1997). A proactive strategic orientation encompasses an aggressive focus on innovations meeting both the articulated and the latent expectations of customers. It promotes the preemptive identification of new market opportunities and acting on those opportunities (Kohli and Jaworski, 1990; Miller and Friesen, 1982). This necessitates an increased level of market intelligence generation and responsiveness. The goal is to lead or alter the competition.

Proactive firms not only focus on responding to explicit customer needs but also explore opportunities for developing new products that customers cannot describe (Atuahene-Gima and Ko, 2001). A market orientation enables a business to anticipate changing market conditions and respond to market requirements (Lukas and Ferrell, 2000) but may only engender incremental changes (Ozsomer, Calantone, and Di Benedetto, 1997). In contrast, if the firm incorporates a strong market orientation into a proactive strategic posture (Calantone, Di Benedetto, and Bhoovaraghavan, 1994), the result is aggressive initiation of product innovation with high levels of risk (Ettlie, Bridges, and O'Keefe, 1984; Hult and Ketchen, 2001; Miller, 1983; Slater and Narver, 1995). Proactiveness and a market focus should provoke the development or improvement of products (i.e., exploitation) and new methods for doing business (i.e., exploration) (Hurley and Hult, 1998; Noble, Sinha, and Kumar, 2002; Ozsomer, Calantone, and Di Benedetto, 1997). With a proactive and aggressive focus on innovations through exploratory learning in addition to adaptive learning, firms may be able to meet latent and unexpressed customer needs (Ozsomer, Calantone, and Di Benedetto, 1997). In short, a proactive strategic orientation should enhance innovativeness (H1).

Successful innovations require a focus on two sources for innovative ideas - namely, an in-house technology push and an external market pull-thus, successful innovations require a proactive focus on the external environment (Calantone, Di Benedetto, and Bhoovaraghavan, 1994; Cooper, 1979, 1992; Song and Parry, 1997). The organizational learning and knowledge literatures acknowledge the need for firms to gather market-related information but emphasize combining exploitation and exploration to achieve effectiveness (Atuahene-Gima and Ko, 2001; Glazer, 1991; Grant, 1991, 1996; Sinkula, 1994). Thus, a proactive strategic orientation motivates the need for market knowledge (Day, 1994; Li and Calantone, 1998; Moorman, 1995). Hence, proactive strategic orientations encourage market intelligence activities (H2).

Having argued $\mathrm{H} 1$ and $\mathrm{H} 2$, the following question is addressed: Are these hypotheses moderated by turbulence? Some studies employed environmental factors as a moderator of the relationship between organizational orientations and performance. For example, a proactive orientation may be more necessary for success in highly competitive, hostile markets than in markets where competition is weak (e.g., AtuaheneGima, 1995; Gatignon and Xuereb, 1997; Homburg and Pflesser, 2000; Kohli and Jaworski, 1990; Ottum and Moore, 1997; Slater and Narver, 1995). However, in the model proactive strategic orientation contributes to new product outcomes through innovativeness and market intelligence (i.e., there is no direct relationship from proactive strategic orientation to new product success). Thus, the domain of the relationships in $\mathrm{H} 1$ and $\mathrm{H} 2$ are restricted to within the boundaries of the organization, and a moderating effect of environmental forces is not expected. Hence,

H1: Proactive strategic orientation will have a positive effect on innovativeness (no moderation hypothesized). H2: Proactive strategic orientation will have a positive effect on market intelligence (no moderation hypothesized).

Regarding the relationship between strategic orientation and organizational structure (H3 in Figure 1), the resource-based view and industrial organization perspectives corroborate that strategy generally determines structure (Miles et al., 1978; Miller, 1983; 
Miller, Droge, and Toulouse, 1988; Miller and Friesen, 1978). The resource-based view maintains that firms match their capabilities to external conditions to gain competitive advantage (Mahoney and Pandian, 1992; Peteraf, 1993). The industrial organization framework argues that external factors are the determinants of the firm's strategy and structure, which in turn at least partly determine economic performance (Miller and Friesen, 1978; Porter, 1981).

Structure is considered the result of a firm's strategic focus on the external environment (Matsuno, Mentzer, and Ozsomer, 2002): The more proactive and aggressive strategic posture is, the more flexible and organic structure is likely to be (Calantone, Di Benedetto, and Bhoovaraghavan, 1994; Calantone, Garcia, and Droge, 2003; Day, 1994). Thus, a proactive strategic orientation requires organicity (i.e., flexible, informal and decentralized structures; see Gupta et al., 1986; Matsuno, Mentzer, and Ozsomer, 2002). Moreover, this relationship should hold irrespective of the level of turbulence. Thus,

H3: Proactive strategic orientation will have a positive effect on organicity in organizational structure (no moderation hypothesized).

\section{The Effects of Organizational Structure (H4, H5)}

A critical problem for firms is to create and work within organizational structures that (1) effectively coordinate the NPD process, (2) facilitate the sharing of information and other resources across functional areas, and (3) provide mechanisms for decision-making and conflict resolution (Achrol, 1991; Adams, Day, and Dougherty, 1998; Henard and Szymanski, 2001; Maltz and Kohli, 1996; Olson, Walker, and Ruekert, 1995; Ottum and Moore, 1997; Song and Montoya-Weiss, 1998; Song, Montoya-Weiss, and Schmidt, 1997; Song, Thieme, and Xie, 1998; Souder, Sherman, and Davies-Cooper, 1998). The organizational literature proposes that uncertain tasks such as complex innovation projects cannot be successfully pursued in highly centralized, bureaucratic structures (Covin and Slevin, 1988, 1989; Hage and Dewar, 1973; Miller, Droge, and Toulouse, 1988). In contrast, since organic structures are characterized by informality and flexibility they may encourage intelligence gathering, enhance receptivity to new technology, and facilitate innovation (Dewar and
Dutton, 1986; Matsuno, Mentzer, and Ozsomer, 2002; Olson, Walker, and Ruekert, 1995; Utterback and Abernathy, 1975). Thus, in general, organicity in organizational structure should lead to enhanced innovativeness and market intelligence activities (as proposed in $\mathrm{H} 4$ and $\mathrm{H} 5$ ).

Surprisingly, in the innovation literature, the empirical findings regarding centralization and formalization (two key aspects of structure) have been inconsistent. Tatikonda (1999) contended that centralization may actually facilitate innovativeness by reducing conflict and ambiguity, thus leading to a more uniform response to changes (Meyers, Sivakumar, and Nakata, 1999). In contrast, Bourgeois and Eisenhardt (1988) argued that firms should be less centralized under conditions of high uncertainty and change. Decentralization, which gives individuals greater autonomy to decide and act, may lead to more exchanges of disperse ideas. Exchanges familiarize employees with changes in the status quo and decrease the associated uncertainty (Ayers, Dahlstrom, and Skinner, 1997; Hage and Dewar, 1973; Tatikonda, 1999). Studies on the impact of formalization also present opposing views. For instance, Ayers, Dahlstrom, and Skinner (1997) asserted that formalized procedures can regulate tasks and assign role responsibilities, thus facilitating input and involvement from other departments. The opposite (and dominant) view is that formalization engenders and enforces the status quo and inhibits the diffusion and communication of ideas. Thus, the empirical evidence for $\mathrm{H} 4$ and $\mathrm{H} 5$ is decidedly mixed.

The next question addressed is whether the relationships from organizational structure to innovativeness and market intelligence are moderated by turbulence. The organizational literature largely maintains that bureaucratic structures can enhance performance under stable conditions (Covin and Slevin, 1989; Khandwalla, 1976-1977; Souder, Sherman, and Davies-Cooper, 1998; Souder and Song, 1998). Meanwhile, flexible and less formalized structures facilitate effective and efficient adjustment to turbulent environments since they allow the free flow of information and resources across departments (Calantone, Di Benedetto, and Bhoovaraghavan, 1994; Calantone, Garcia, and Droge, 2003; Ozsomer, Calantone, and Di Benedetto, 1997; Utterback and Abernathy, 1975). Organizational structure serves as a medium that allows the transfer and incorporation of knowledge within departments: knowledge of what is needed in the market and how to create a product to meet 
the need. Accordingly, it is hypothesized that the impact of organizational structure on new product success will be mediated by innovativeness and market intelligence; that is, the impact of structure on new product success is hypothesized as indirect (Figure 1). New product success occurs outside of the firm in the marketplace, and it is only when the new product efforts of the firm are put to the market test that the moderating effects of turbulence will be seen. In other words, the moderating effects of turbulence will be not be evident in $\mathrm{H} 4$ or $\mathrm{H} 5$ (but will be seen in $\mathrm{H} 7$ and $\mathrm{H} 8$ ):

H4: Organicity in organizational structure will have a positive effect on innovativeness (no moderation hypothesized).

H5: Organicity in organizational structure will have a positive effect on market intelligence (no moderation hypothesized).

\section{The Effect of Innovativeness on Market Intelligence (H6)}

Innovative firms, or prospectors in Miles and Snow (1978), focus primarily on finding and exploiting new product and market opportunities. They are more likely to undertake really new or radical innovations, which represent a great departure or exhibit discontinuity from existing practices (De Brentani 2001; Gatignon and Xuereb, 1997; Song and Montoya-Weiss, 1998). But discontinuity is risky and entails considerable uncertainty (Gatignon and Xuereb, 1997; Souder and Song, 1997). A huge gap may exist between the amount of information required and the amount of information already possessed by the firm. To be more innovative, more learning and change are required, and uncertainty must be reduced through market information processing (Ottum and Moore, 1997). Thus,

H6: Innovativeness will have a positive effect on market intelligence (no moderation hypothesized).

\section{The Effects of Innovativeness and Market Intelligence on NP Success (H7, H8)}

The basic assumption of resource-based view is that firms that have superior resources (i.e., rare, nonimitable, and nonsubstitutable) will gain rents and competitive advantages in the marketplace (Mahoney and
Pandian, 1992; Peteraf, 1993). Correspondingly, a company developing a superior, unique, and novel product should enjoy competitive market advantage and financial success (Griffin and Page, 1996; Hult and Ketchen, 2001). However, empirical NPD studies show that the influence innovativeness exerts on new product outcomes is not so clear. For some researchers, more innovative products should create more opportunities for differentiation and competitive advantage (Cooper and Kleinschmidt, 1991; Gatignon and Xuereb, 1997; Han, Kim, and Srivastava, 1998; Song and Parry, 1996). In contrast, other studies indicate that less innovative products are more familiar, less uncertain, may have higher synergies, and hence have a higher success rate (Cooper and Kleinschmidt, 1991). In particular, the results of Tatikonda's (1999) empirical study, as well as Montoya-Weiss and Calantone's (1994) meta-analytic study, demonstrate a lack of significant relationships between innovativeness constructs and new product success.

These conflicting results can be addressed with a contingency perspective, specifically by investigating moderation by turbulence. Turbulent environments are characterized by uncertainty, unpredictability, continuously emerging or eroding temporary competitive advantages, and low barriers to entry/exit (Atuahene-Gima, 1995; Bourgeois and Eisenhardt, 1988; Calantone, Garcia, and Droge, 2003; Calantone, Schmidt, and Di Benedetto, 1997; Covin and Slevin, 1988; Miller and Friesen, 1978; Ozsomer, Calantone, and Di Benedetto, 1997). Sources for turbulence include technological innovations (which cause rapid product obsolescence), continuous changes in customers' preferences or demands, changes in price or cost structures, and the dynamics of competition (Calantone, Di Benedetto, and Bhoovaraghavan, 1994; Calantone, Garcia, and Droge, 2003; Calantone, Schmidt, and Di Benedetto, 1997; Han, Kim, and Srivastava, 1998; Li and Calantone, 1998; Montoya-Weiss and Calantone, 1994; Moorman and Miner, 1997; Mullins and Sutherland, 1998; Souder, Sherman, and DaviesCooper, 1998). Such dynamic conditions may further lead to difficulties in obtaining accurate and timely information, render obsolete a firm's formal assessment system, or signal the opening of opportunities (Calantone, Schmidt, and Di Benedetto, 1997).

The environment in which a firm competes is not under direct managerial control (in the short run, at least). Thus, it is argued that for a given level of innovativeness, less new product success will be achieved under turbulent conditions. Another way 
of looking at this issue is that for a given desired level of new product success, more innovativeness is required from managers and their firms under turbulent environmental conditions (Miller, Droge, and Toulouse, 1988). In other words, the relationship between innovativeness and new product success is moderated by turbulence (Covin and Slevin, 1989; Song and Parry, 1997):

H7: The relationship between innovativeness and new product success will be positive. This relationship (i.e., the beta) will be weaker in highly turbulent environments compared with low-turbulence environmental settings.

Market intelligence, the subject of $\mathrm{H} 8$, is considered to be a firm competence ( $\mathrm{Li}$ and Calantone, 1998; Li, Nicholls, and Roslow, 1999; Moorman, 1995). Competence in the gathering, sharing, or use of market information is a strategic asset of the firm (Day, 1994; Glazer, 1991). The collection and dissemination of market intelligence provides a mechanism to obtain market information (Calantone, Garcia, and Droge, 2003), linking markets and NPD activities ( $\mathrm{Li}$ and Calantone, 1998; Moorman, 1995). More specifically, customer knowledge enables the firm to explore emerging market demand (Cooper, 1992; Slater and Narver, 1995), and competitor knowledge allows a firm to benchmark and possibly alter competitive dynamics. Therefore, market intelligence has been the most prevalently hypothesized antecedent of new product success (Moorman and Miner, 1997; Ottum and Moore, 1997). Hence, H8 is proposed that market intelligence and new product success are positively related.

However, several studies in the new product and market orientation literatures have shown that turbulent environments require stronger market orientations or more market information processing to achieve new product success (Homburg and Pflesser, 2000; Mullins and Sutherland, 1997; Narver and Slater, 1990; Ottum and Moore, 1997). In rapidly changing markets, NPD managers are faced with uncertainty about market opportunities, customers' inability to articulate needs, or risky decisions about when and how much capital to invest. Consequently, firms need to process more information to support decision making (Damanpour, 1991; Souder and Song, 1998); that is, turbulence forces the firm to search for and process more information for a given level of success (Moorman and Miner, 1997). Since it reduces the value of prior learning, turbulence will negatively moderate the relationship between market intelligence and new product outcomes. Thus,

\begin{abstract}
H8: The relationship between market intelligence and new product success will be positive. This relationship will be significantly weaker in highly turbulent environments compared with low-turbulence environmental settings.
\end{abstract}

\section{Method}

\section{Sampling Frame}

The sampling frame was composed of 346 manufacturers on the Fortune 500. Prior to sending a mail questionnaire, each firm was contacted by phone to encourage participation by the correct key informant. Guidelines by Campbell (1955) were followed. Respondents were senior managers with responsibilities for product innovation or management at the strategic business unit (SBU) level. A wide variety of job titles were observed, including product manager, R\&D manager, and NPD manager. A telephone follow-up and a second mailing generated 202 usable questionnaires (58\% of 346 mailed) across 41 industries. SBUs had average annual sales of $\$ 4.6$ billion and average annual R\&D budgets of $\$ 360.4$ million and generated approximately $8.16 \%$ of their sales from products introduced in the last five years.

\section{Measurement}

Respondents provided information for their latest new product project. All scales and Cronbach's alphas are shown in the Appendix. The reliability coefficients ranged from 0.75 to 0.875 and thus were acceptable (Nunnally, 1978) (see also Table 1).

Environmental turbulence was gauged using Miller and Droge's (1986) scale, which incorporates Khandwalla's (1976-1977) and Miller's (1983) measures $(\alpha=0.775)$. The three items for innovativeness were taken from Miller and Friesen (1982) $(\alpha=0.830)$. The three items for proactive strategic orientation were adapted from Covin and Slevin (1988) $(\alpha=0.874)$. Organizational structure (organicity) was measured using three items taken from Khandwalla (1976-1977) $(\alpha=0.875)$. The three market intelligence items were developed using 11-point Likert-type scales $(\alpha=0.856)$. Finally, to measure the degree of 
Table 1. Reliabilities and Correlations among Constructs ${ }^{\mathrm{a}}$

\begin{tabular}{|c|c|c|c|c|c|c|c|}
\hline & Constructs & 1 & 2 & 3 & 4 & 5 & 6 \\
\hline 1 & New Product Success & $(0.751)$ & & & & & \\
\hline 2 & Environmental Turbulence & 0.041 & $(0.775)$ & & & & \\
\hline 3 & Proactive Strategic Orientation & 0.498 & 0.198 & $(0.874)$ & & & \\
\hline 4 & Org. Structure (Organicity) & 0.340 & 0.182 & 0.773 & $(0.875)$ & & \\
\hline 5 & Innovativeness & 0.439 & 0.505 & 0.712 & 0.663 & $(0.830)$ & \\
\hline 6 & Market Intelligence & 0.553 & -0.049 & 0.284 & 0.090 & 0.158 & $(0.856)$ \\
\hline
\end{tabular}

${ }^{a}$ Cronbach's alpha on the diagonal; correlations are from the confirmatory factor analysis phi matrix.

new product success, respondents rated financial success on two 11-point scales $(\alpha=0.751)$. All items were specified as reflective indicators loading on their respective constructs.

\section{Measurement Model Validation}

The data were analyzed using a two-step approach, separating the measurement model from the structural model (Anderson and Gerbing, 1988). A confirmatory factor analysis (CFA) using maximum likelihood EQS version 6.1 (Bentler, 1995) was performed first (Bollen, 1989; Hoyle, 1995). The $\chi^{2}$ was 176.332 ( $\mathrm{df}=104)$, the Bentler-Bonnet non-normed fit index (NNFI) was 0.949, the comparative fit index (CFI) was 0.961 , and the root mean square error of approximation (RMSEA) was 0.059. The largest standardized residual was 0.165 (i.e., less than 2.00). Thus overall, the measurement model fits well.

Convergent and discriminant validities were then assessed. All the variables have loadings more than 0.65 , indicating convergent validity (see the Appendix). Only the first eigenvalue of a principal component analysis with varimax rotation was greater than 1 when each construct was evaluated separately. This supports unidimensionality of the constructs. Discriminant validity at the item level was shown by the lack of significant cross-loadings as indicated by a Langrangian multiplier (LM) test. Moreover, a model with construct correlations constrained to 1.00 was compared with an unconstrained model. This led to a significant increase in chi-squared, and LM tests revealed that these constraints should be removed. Thus, all constructs exhibited discriminant validity.

\section{Analyses and Results}

The sample was split into two groups by the median value of the turbulence construct (i.e., 3.67) to scrutinize the moderating effects of environment $\left(n_{\text {low }}=103, n_{\text {high }}=98\right)($ Bollen, 1989 , p. 355; Calantone, Garcia, and Droge, 2003, p. 98; Calantone, Schmidt, and Song, 1996, p. 348). A two-group CFA with LM tests was performed to verify that measurement was consistent across the two groups, as it should be because the groups come from the same population (Bollen, 1989, p. 359; Kaplan, 1995, p. 63). The factor loadings were set equal across groups, and the results indicated that constructs across groups were composed of equal and significantly loading indicators $(p<.05 ; \mathrm{LM}$ tests showed no differences for all 17 factor loadings). Furthermore, overall fit indices indicated adequate fit $(\mathrm{NNFI}=0.928, \quad \mathrm{CFI}=0.942$, RMSEA $=0.058$ ). Thus the measurement model was declared invariant across the two turbulence groups.

Then two-group SEM using EQS was employed to test the full structural model in Figure 1(Bollen, 1989; Bentler, 1995; Hoyle, 1995; Kaplan, 1995). In particular, it was tested whether the strengths of the structural paths were moderated by turbulence (i.e., varied across turbulence groups). A fully constrained model was specified by restricting the path coefficients equal across groups. This model was compared with an unconstrained model, and LM tests revealed which restrictions did not hold. The results are presented in Tables 2 (path coefficients for the hypotheses), 3 (tests for moderation), and 4 (indirect and total effects).

The overall fit indicators were $\chi^{2}=251.054(\mathrm{df}=$ 153), $\mathrm{NNFI}=0.931, \mathrm{CFI}=0.942$, and $\mathrm{RMSEA}=$ 0.057 . Thus, the two group model fits well overall. Proactiveness is positively related to innovativeness, market intelligence, and organizational structure, supporting $\mathrm{H} 1, \mathrm{H} 2$, and $\mathrm{H} 3$ (all $p<.01$; Table 2). Organizational structure had a positive effect on innovativeness, supporting $\mathrm{H} 4$, but it had a negative effect on market intelligence, contradicting H5. The relationship between innovativeness and market intelligence was not significant; thus, H6 was rejected. As shown in Table 3, LM tests revealed no significant difference in chi-square (at 0.05 ) if the equality restrictions are removed, supporting the contention concerning equality across groups 
Table 2. Fit Statistics and Path Coefficients ${ }^{\mathrm{a}}$

\begin{tabular}{|c|c|c|c|c|}
\hline Predictor & Criterion & Hypothesis & Unstandardized Estimates & Standardized Estimates \\
\hline Proactive Strategic Orientation & Innovativeness & $\mathrm{H} 1$ & $\begin{array}{l}.667(t=4.782) \\
(\text { set equal) }\end{array}$ & $\begin{array}{l}\gamma_{1} \text { low }=.473 \\
\text { high }=.640\end{array}$ \\
\hline Proactive Strategic Orientation & Market Intelligence & $\mathrm{H} 2$ & $\begin{array}{l}.690(t=3.070) \\
(\text { set equal) }\end{array}$ & $\begin{array}{l}\gamma_{2} \text { low }=.479 \\
\text { high }=.577\end{array}$ \\
\hline Proactive Strategic Orientation & $\begin{array}{l}\text { Organizational Structure } \\
\text { (Organicity) }\end{array}$ & $\mathrm{H} 3$ & $\begin{array}{l}.944(t=10.696) \\
\text { (set equal) }\end{array}$ & $\begin{array}{l}\gamma_{3} \text { low }=.700 \\
\text { high }=.836\end{array}$ \\
\hline Organizational Structure (Organicity) & Innovativeness & $\mathrm{H} 4$ & $\begin{array}{l}.245(t=2.200) \\
\text { (set equal) }\end{array}$ & $\begin{array}{l}\beta_{1} \text { low }=.234 \\
\text { high }=.266\end{array}$ \\
\hline Organizational Structure (Organicity) & Market Intelligence & H5 & $\begin{array}{l}-.401(t=-2.554) \\
\text { (set equal) }\end{array}$ & $\begin{array}{l}\beta_{2} \text { low }=-.375 \\
\text { high }=-.378\end{array}$ \\
\hline Innovativeness & Market Intelligence & H6 & $\begin{array}{l}.088 \text { (n.s.) } \\
\text { (set equal) }\end{array}$ & $\begin{array}{l}\beta_{3} \text { low }=.086 \text { (n.s.) } \\
\text { high }=.076 \text { (n.s.) }\end{array}$ \\
\hline Innovativeness & New Product Success & $\mathrm{H} 7$ & $\begin{array}{l}\text { low }=.155(\text { n.s. }) \\
\text { high }=1.297(t=7.376)\end{array}$ & $\begin{array}{l}\beta_{4} \text { low }=.109 \text { (n.s.) } \\
\text { high }=.765\end{array}$ \\
\hline Market Intelligence & New Product Success & $\mathrm{H} 8$ & $\begin{array}{l}\text { low }=1.056(t=7.125) \\
\text { high }=.142(\text { n.s. })\end{array}$ & $\begin{array}{l}\beta_{5} \text { low }=.755 \\
\text { high }=.096 \text { (n.s.) }\end{array}$ \\
\hline
\end{tabular}

${ }^{\mathrm{a}}$ Fit indices: Chi-square $=251.054(\mathrm{df}=153) p<.001$; non-normed fit index $(\mathrm{NNFI})=0.931$, comparative fit index $(\mathrm{CFI})=0.942$, root mean square error of approximation $($ RMSEA $)=0.057$. All estimates are significant at 0.05 except where indicated as nonsignificant (n.s.).

for these intraorganizational relationships. No path coefficient in $\mathrm{H} 1$ through $\mathrm{H} 6$ was moderated by turbulence (high vs. low). Note that in Tables 2 and 4, the unstandardized estimates are the same for $\mathrm{H} 1$ through H6 because the paths were set equal; the standardized estimates will differ across groups because the standard errors of the estimates differ.

The effects of innovativeness (H7) and market intelligence $(\mathrm{H} 8)$ on new product success were significantly different across levels of turbulence (at 0.01 , as suggested by our LM test results in Table 3). It was concluded that paths spanning boundaries are impacted by turbulence. The effect of innovativeness on new product success was positive in the high turbulence group but nonsignificant in the low turbulence group (Table 2). Since the opposite had been hypothesized (i.e., that the effect would be greater in the low turbulence group), H7 is not supported. Market intelligence, on the other hand, had a positive impact in the low turbulence group but was not significantly related to new product success in the high turbulence group, partially supporting $\mathrm{H} 8$.

Finally, note that tests for the existence of direct effects of either proactive strategic orientation or organicity on new product success showed that these direct effects were nonsignificant. Thus, the impact of either proactive strategic orientation or organicity on new product success is completely mediated by (i.e., indirect through) innovativeness and market intelligence. Table 4, containing all indirect and total

\section{Table 3. Results of Tests for Moderation}

\begin{tabular}{|c|c|c|c|c|}
\hline Predictor & Criterion & Hypothesis & $\chi^{2} \mathrm{diff} / \mathrm{p}$ & Conclusion \\
\hline Proactive Strategic Orientation & Innovativeness & $\mathrm{H} 1$ & $0.723(p=.395)$ & $\begin{array}{l}\text { Equal; } \\
\text { H1 not moderated }\end{array}$ \\
\hline Proactive Strategic Orientation & Market Intelligence & $\mathrm{H} 2$ & $0.353(p=.552)$ & $\begin{array}{l}\text { Equal; } \\
\text { H2 not moderated }\end{array}$ \\
\hline Proactive Strategic Orientation & Organizational Structure (Organicity) & $\mathrm{H} 3$ & $0.710(p=.399)$ & $\begin{array}{l}\text { Equal; } \\
\text { H3 not moderated }\end{array}$ \\
\hline Organizational Structure (Organicity) & Innovativeness & $\mathrm{H} 4$ & $2.276(p=.131)$ & $\begin{array}{l}\text { Equal; } \\
\text { H4 not moderated }\end{array}$ \\
\hline Organizational Structure (Organicity) & Market Intelligence & H5 & $1.380(p=.240)$ & $\begin{array}{l}\text { Equal; } \\
\text { H5 not moderated }\end{array}$ \\
\hline Innovativeness & Market Intelligence & H6 & $1.919(p=.166)$ & $\begin{array}{l}\text { Equal; } \\
\text { H6 not moderated }\end{array}$ \\
\hline Innovativeness & New Product Success & $\mathrm{H} 7$ & $16.943(p=.000)$ & $\begin{array}{l}\text { Unequal; } \\
\text { H7 moderated }\end{array}$ \\
\hline Market Intelligence & New Product Success & $\mathrm{H} 8$ & $14.301(p=.000)$ & $\begin{array}{l}\text { Unequal; } \\
\text { H8 moderated }\end{array}$ \\
\hline
\end{tabular}


Table 4. Indirect and Total Effects ${ }^{\mathrm{a}}$

\begin{tabular}{|c|c|c|c|c|c|}
\hline PREDICTOR & CRITERION & $\begin{array}{c}\text { Indirect Effect: } \\
\text { Unstandardized } \\
\text { estimates }\end{array}$ & $\begin{array}{l}\text { Indirect Effect: } \\
\text { Standard } \\
\text { Estimates }\end{array}$ & $\begin{array}{c}\text { Total Effect: } \\
\text { Unstandardized } \\
\text { Estimates }\end{array}$ & $\begin{array}{l}\text { Total Effect: } \\
\text { Standard } \\
\text { Estimates }\end{array}$ \\
\hline $\begin{array}{l}\text { Proactive Strategic } \\
\text { Orientation }\end{array}$ & Innovativeness & $\begin{array}{l}.232(t=2.207) \\
\text { (set equal) }\end{array}$ & $\begin{array}{l}\text { Low }=.164 \\
\text { High }=.222\end{array}$ & $\begin{array}{l}.899(t=9.406) \\
\text { (set equal) }\end{array}$ & $\begin{array}{l}\text { Low }=.637 \\
\text { high }=.862\end{array}$ \\
\hline $\begin{array}{l}\text { Proactive Strategic } \\
\text { Orientation }\end{array}$ & $\begin{array}{l}\text { Market } \\
\text { Intelligence }\end{array}$ & $\begin{array}{l}-.299(t=-1.632) \\
\text { (set equal) }\end{array}$ & $\begin{array}{l}\text { Low }=-.208 \\
\text { High }=-.250\end{array}$ & $\begin{array}{l}.391(t=3.714) \\
\text { (set equal) }\end{array}$ & $\begin{array}{l}\text { Low }=.271 \\
\text { High }=.326\end{array}$ \\
\hline $\begin{array}{l}\text { Organizational } \\
\text { Structure (Organicity) }\end{array}$ & $\begin{array}{l}\text { Market } \\
\text { Intelligence }\end{array}$ & $\begin{array}{l}.022 \text { (n.s.) } \\
\text { (set equal) }\end{array}$ & $\begin{array}{l}\text { Low }=.020 \\
\text { High }=.020\end{array}$ & $\begin{array}{l}-.379(t=-2.460) \\
\text { (set equal) }\end{array}$ & $\begin{array}{l}\text { Low }=-.355 \\
\text { High }=-.358\end{array}$ \\
\hline $\begin{array}{l}\text { Proactive Strategic } \\
\text { Orientation }\end{array}$ & $\begin{array}{l}\text { New Product } \\
\text { Success }\end{array}$ & $\begin{array}{l}\text { Low }=.552(t=3.518) \\
\text { High }=1.221(t=7.617)\end{array}$ & $\begin{array}{l}\text { Low }=.274 \\
\text { High }=.691\end{array}$ & $\begin{array}{l}\text { Low }=.552(t=3.518) \\
\text { High }=1.221(t=7.617)\end{array}$ & $\begin{array}{l}\text { Low }=.274 \\
\text { High }=.691\end{array}$ \\
\hline $\begin{array}{l}\text { Organizational } \\
\text { Structure (Organicity) }\end{array}$ & $\begin{array}{l}\text { New Product } \\
\text { Success }\end{array}$ & $\begin{array}{l}\text { Low }=-.362(t=-2.101) \\
\text { High }=.264(t=1.655)\end{array}$ & $\begin{array}{l}\text { Low }=-.242 \\
\text { High }=.169\end{array}$ & $\begin{array}{l}\text { Low }=-.362(t=-2.101) \\
\text { High }=.264(t=1.655)\end{array}$ & $\begin{array}{l}\text { Low }=-.242 \\
\text { High }=.169\end{array}$ \\
\hline Innovativeness & $\begin{array}{l}\text { New Product } \\
\text { Success }\end{array}$ & $\begin{array}{l}\text { Low }=.093 \text { (n.s.) } \\
\text { High }=.012 \text { (n.s.) }\end{array}$ & $\begin{array}{l}\text { Low }=.065 \\
\text { High }=.007\end{array}$ & $\begin{array}{l}\text { Low }=.247 \text { (n.s. }) \\
\text { High }=1.309(t=7.467)\end{array}$ & $\begin{array}{l}\text { Low }=.173 \\
\text { High }=.773\end{array}$ \\
\hline
\end{tabular}

${ }^{a}$ All estimates are significant at $p<.05$ except where indicated nonsignificant (n.s.).

effects, shows that (1) the total effect of a proactive strategic orientation on new product success is positive in each turbulence group (standard effect low $=0.274$, high $=0.691$ ); and (2) the total effect of organicity on new product success is also significant in each turbulence group but is significantly positive when turbulence is high (0.169) and significantly negative when turbulence is low $(-0.242)$.

\section{Discussion}

NPD is inherently a high risk and difficult venture. The model proposed that a proactive strategic orientation and an organic organizational structure impact innovativeness and market intelligence, which in turn are antecedents to new product success. The research scrutinized the moderating impact of environmental turbulence on these relationships, and the results show that the hypothesized paths among intraorganizational constructs (i.e., among strategic orientation, structure, innovativeness and market intelligence) are not moderated by turbulence. However, the paths from intraorganizational constructs to new product success are moderated: Innovativeness was positively related to new product success only in highly turbulent environments, whereas market intelligence had a significant positive impact on new product success only under low turbulence.

Before discussing these results in detail, some limitations should be noted. The measurements were primarily perceptual and collected from single respondents, all of whom were from Fortune 500 firms. Furthermore, the results may not be generalizable to firms that are not of comparable size. Since firm size has frequently been shown to have a major impact in organizational design studies, caution must be exercised in extending these results to small or medium-sized firms. Finally, the environmental turbulence construct was the only moderator scrutinized. It encompassed both market- and technology-derived turbulence and hence taps overall turbulence. It may be, however, that the source of turbulence - that is, where it is derived - impacts either the degree of moderation or the identity of the relationships moderated or both. The discussion of the results begins by focusing on intraorganizational factors.

\section{Intraorganizational Factors}

Positive and significant total effects of proactive strategic orientation on innovativeness and on market intelligence were found (as the organizational literature suggests). Thus, overall, proactive strategies enhance innovativeness and encourage market intelligence activities. However, a decomposition of these total effects into direct versus indirect effects revealed an unexpected result. The direct effects of proactive strategies on innovativeness and on market intelligence were both positive and significant (as hypothesized), but the indirect effects differed in sign and significance. The indirect effect of proactive strategic orientation on innovativeness (through structure) was significant and positive, whereas the indirect effect of proactive strategic orientation on market intelli- 
gence was negative. The origin of the negative sign of the latter relationship lay in two sources. First, the inverse relationship between organizational structure and market intelligence (discussed in detail herein) led to a negative strategy $\rightarrow$ structure $\rightarrow$ intelligence indirect route. Second, the nonsignificant relationship between innovativeness and market intelligence meant that indirect paths through innovativeness could not play a compensatory role. For example, the indirect route through strategy $\rightarrow$ innovativeness $\rightarrow$ intelligence had no impact because the last leg was nonsignificant. The partially unexpected pattern of direct, indirect, and total effects illustrates the importance of effects decomposition analysis in the understanding of model relationships.

The negative relationship found between organizational structure and market intelligence was unexpected. The results suggest that more mechanistic organizational structures (characterized by centralization of decision making and formality) lead to more effective generation and dissemination of market intelligence. Because this path was negative, the total effects of organicity on new product success under conditions of low turbulence was negative as well. These results contradict some literature advocating organicity while supporting other studies in the organizational and new product literature (Bourgeois and Eisenhardt, 1988; Dewar and Dutton, 1986; Meyers, Sivakumar, and Nakata, 1999).

For both researchers and managers, it is germane to examine the processes that enable mechanistic structures to incur more market intelligence (or, equivalently, ways organicity incurs less market intelligence). First, consider the centralization that is characteristic of mechanistic structures. Centralization may foster the efficient transmission and utilization of information and lead to more effective and timely decision making because conflicts and ambiguities are reduced through a higher locus of control. This may lead to the quicker building of consensus and enhanced sharing across departments, thus advancing market intelligence's impact. For managers occupying these higher loci of control, the implications are clear: Speedy consensus and sharing are key. Second, consider the formalization that typically accompanies mechanistic structures. Since formalized procedures can regulate both tasks and roles, formalization may facilitate input from and involvement of other departments, thus leading to more effective sharing (not just faster sharing). Formalization may also be a proxy for programmatic, which may imply a systematic infor- mation-gathering process. Managers should make sure that systematic does not become stifling, however. In general, the relationships between various dimensions of organizational structure and specific aspects of market intelligence require more scrutiny in future research.

For managers, it is important to note that the total effects (direct and indirect) of proactive strategic orientation on market intelligence and on innovativeness were positive and that a proactive strategic orientation also positively impacted organicity in structure. This implies that a proactive strategic orientation is a source that motivates or engenders organicity, market intelligence, and innovativeness: In short, managers should get strategy right first. The prediction of the chain-comprising proactive strategic orientation leading to organic structures, which then further increases innovativeness-was also supported. For managers, this suggests that there are two routes to innovativeness from strategy: one direct (i.e., strategy $\rightarrow$ innovativeness) and one through organicity in structure (i.e., strategy $\rightarrow$ structure $\rightarrow$ innovativeness). In summary, managers should get strategy right first, and then they should get structure right.

\section{The Moderating Effect of Environmental Turbulence}

Turbulence was tapped by measuring market turbulence, competition intensity, and rate of technological change, reflecting the three major sources of uncertainty. Drawing on a contingency perspective, it was proposed that the relationships from intraorganizational factors to new product success varied with environmental turbulence, whereas the relationships among intraorganizational factors did not. This premise was partially supported since the results show that the paths from innovativeness and from market intelligence to new product success were the only two paths moderated by turbulence. However, the exact nature of the moderation found was not what we had originally expected.

The findings show that when turbulence is high, innovativeness is related to new product success whereas market intelligence is not. Turbulent environments are characterized by frequent and dramatic changes, impeding accurate prediction and timely response. Existing knowledge resources become obsolete, consumer have difficulty in articulating what they need or want, and competitors may completely revo- 
lutionize the value proposition by introducing new products. In such circumstances, no returns for additional market intelligence were found, but significantly higher returns for additional innovative capabilities were detected. These findings suggest that, under high turbulence, (1) there are limits to the extent that extra investment in market knowledge will pay off in additional new product success but (2) enhanced innovativeness will pay off. The measures of innovativeness strongly suggest a technology push emphasis, whereas the measures of market intelligence strongly suggest a market pull emphasis. Thus, the results concerning enhanced new product success can be roughly translated as follows: In high turbulence, the marginal payoff of technology push seems to be more than the marginal payoff of market pull. Testing this statement directly is an area for future research.

In contrast, when turbulence is low, market intelligence is related to new product success whereas innovativeness is not. Under conditions of low turbulence, changes are not frequent or dramatic, and thus relatively accurate prediction and subsequent timely response are possible. Customers can often articulate what they need or want, and predicting competitors' actions is relatively straightforward. In this case, substantial returns for additional market intelligence were found, but no significantly higher returns for additional innovative capabilities. These results for enhancing new product success in low-turbulence environments can be roughly translated as follows: The marginal payoff of market pull is more than the marginal payoff of technology push.

\section{References}

Achrol, R.S. (1991). Evolution of the Marketing Organization: New Forms for Turbulent Environments. Journal of Marketing 55(4):77-93.

Adams, M.E., Day, G.S., and Dougherty, D. (1998). Enhancing New Product Development Performance: An Organizational Learning Perspective. Journal of Product Innovation Management 15(1):403422.

Anderson, J. and Gerbing, D. (1988). Structural Equation Modeling in Practice: A Review and Recommended Two-Step Approach. Psychological Bulletin 103(3):411-423.

Atuahene-Gima, K. (1995). An Exploratory Analysis of the Impact of Market Orientation on New Product Performance: A Contingency Approach. Journal of Product Innovation Management 12(4):275-293.

Atuahene-Gima, K. and Ko, A. (2001). An Empirical Investigation of the Effect of Market Orientation and Entrepreneurship Orientation on Product Innovation. Organization Science 12(1):54-74.

Ayers, D., Dahlstrom, R., and Skinner, S.J. (1997). An Exploratory Investigation of Organizational Antecedents to New Product Success. Journal of Marketing Research 34(1):107-116.
Bentler, P.M. (1995). EQS Structural Equations Program Manual. Encino, CA: Multivariate Software, Inc.

Bollen, K.A. (1989). Structural Equation with Latent Variables. New York: John Wiley\& Sons, Inc.

Bourgeois, L.J. and Eisenhardt, K.M. (1988). Strategic Decision Process in High Velocity Environments: Four Cases in Microcomputer Industry. Management Science 34(7):816-835.

Brown, S.L. and Eisenhardt, K.M. (1997). The Art of Continuous Change: Linking Complexity Theory and Time-Paced Evolution in Relentlessly Shifting Organizations. Administrative Science Quarterly 42(1):1-34.

Calantone, R.J. and Di Benedetto, C.A. (1988). An Integrative Model of New Product Development Process: An Empirical Validation. Journal of Product Innovation Management 5(3):201-215.

Calantone, R., Di Benedetto, C.A., and Bhoovaraghavan, S. (1994). Examining the Relationship between Degree of Innovation and New Product Success. Journal of Business Research 30(3):143148.

Calantone, R., Garcia, R., and Droge, C. (2003). The Effects of Environmental Turbulence on New Product Development Strategy Planning. Journal of Product Innovation Management 20(2): 90-103.

Calantone, R.J., Schmidt, J.B., and Di Benedetto, C.A. (1997). New Product Activities and Performance: The Moderating Role of Environmental Hostility. Journal of Product Innovation Management 14(3):179-189.

Calantone, R.J., Schmidt, J.B., and Song, X.M. (1996). Controllable Factors of New Product Success: A Cross-National Comparison. Marketing Science 15(4):341-358.

Campbell, D.T. (1955). The Informant in Quantitative Research. American Journal of Sociology 60:339-342.

Cooper, R.G. (1979). Identifying Industrial New Product Success: Project NewProd. Journal of Marketing 43:93-103. (Summer).

Cooper, R.G. (1992). The NewProd System: The Industry Experience. Journal of Product Innovation Management 9(2):113-127.

Cooper, R.G. and Kleinschmidt, E.J. (1991). The Impact of Product Innovativeness on Performance. Journal of Product Innovation Management 8(4):240-252.

Covin, J.G. and Slevin, D.P. (1988). The Influence of Organizational Structure on the Utility of an Entrepreneurial Top Management Style. Journal of Management Studies 25(3):217-234.

Covin, J.G. and Slevin, D.P. (1989). Strategic Management of Small Firms in Hostile and Benign Environments. Strategic Management Journal 10(1):75-87.

Damanpour, F. (1991). Organizational Innovation: A Meta-Analysis of Effects of Determinants and Moderators. Academy of Management Journal 34(3):555-591.

Danneels, E. and Kleinschmidt, E.J. (2001). Product Innovativeness from the Firm's Perspective: Its Dimensions and Their Relation with Project Selection and Performance. Journal of Product Innovation Management 18(6):357-373.

Day, G.S. (1994). The Capabilities of Market-Driven Organizations. Journal of Marketing 58(4):37-52.

De Brentani, U. (2001). Innovative versus Incremental New Business Services: Different Keys for Achieving Success. Journal of Product Innovation Management 18(4):169-187.

Dewar, R.D. and Dutton, J.E. (1986). The Adoption of Radical and Incremental Innovations: An Empirical Analysis. Management Science (1986-1998) 32(11):1422-1433.

Di Benedetto, C.A. (1999). Identifying the Key Success Factors in New Product Launch. Journal of Product Innovation Management 16(6):530-544.

Ettlie, J.E., Bridges, W.P., and O'Keefe, R.D. (1984). Organization Strategy and Structural Differences for Radical Versus Incremental Innovation. Management Science 30(6):682-696. 
Gatignon, H. and Xuereb, J.M. (1997). Strategic Orientation of the Firm and New Product Performance. Journal of Marketing Research 34(1):77-90.

Glazer, R. (1991). Marketing in an Information-Intensive Environment: Strategic Implications of Knowledge as an Asset. Journal of Marketing 55(4):1-19.

Grant, R.M. (1991). The Resource-Based Theory of Competitive Advantage: Implications for Strategy Formulation. California Management Review 33(3):114-135.

Grant, R.M. (1996). Toward a Knowledge-Based Theory of the Firm. Strategic Management Journal 17:109-122 (Winter Special Issue).

Griffin, A. and Page, A.L. (1996). PDMA Success Measurement Project: Recommended Measures for Product Development Success and Failure. Journal of Product Innovation Management 13(6):478496.

Gupta, A.K., Raj, S.P., and Wilemon, D. (1986). The R\&D Marketing Interface in High-Technology Firms. Journal of Product Innovation Management 2(6):12-24.

Hage, J. and Dewar, R. (1973). Elite Values versus Organizational Structure in Predicting Innovation. Administrative Science Quarterly 18(3):279-290.

Han, J.K., Kim, N., and Srivastava, R.K. (1998). Market Orientation and Organizational Performance: Is Innovation a Missing Link? Journal of Marketing 62(4):30-45.

Henard, D.H. and Szymanski, D.M. (2001). Why Some New Products Are More Successful than Others. Journal of Marketing Research 38(3):362-375.

Homburg, C. and Pflesser, C. (2000). A Multi-layer Model of MarketOriented Organizational Culture: Measurement Issues and Performance Outcomes. Journal of Marketing Research 37:449-462 (November).

Hoyle, R.H. (1995). Structural Equation Modeling: Concepts, Issues and Applications. Thousand Oaks, CA: Sage Publications, Inc.

Hult, G.T.M. and Ketchen, D.J. Jr. (2001). Does Market Orientation Matter? A Test of the Relationship between Positional Advantage and Performance. Strategic Management Journal 22(9):899-906.

Hultink, E.J., Griffin, A., Hart, S., and Robben, H.S.J. (1997). Industrial New Product Launch Strategies and Product Development Performance. Journal of Product Innovation Management 14(4):243-257.

Hurley, R.F. and Hult, G.T.M. (1998). Innovation, Market Orientation, and Organizational Learning: An Integration and Empirical Examination. Journal of Marketing 62(3):42-54.

Kaplan, D. (1995). Structural Equation Modeling: Foundations and Extensions. Thousand Oaks, CA: Sage Publications, Inc.

Khandwalla, P.N. (1976-1977). Some Top Management Styles, Their Context and Performance. Organization Administrative Science 7(4):21-51.

Kohli, A.K. and Jaworski, B.J. (1990). Market Orientation: The Construct, Research Propositions and Managerial Implications. Journal of Marketing 54(2):1-18.

Lukas, B.A. and Ferrell, O.C. (2000). The Effect of Market Orientation on Product Innovation. Academy of Marketing Science Journal 28(2):239-248.

Li, T. and Calantone, R.J. (1998). The Impact of Market Knowledge Competence on New Product Advantage: Conceptualization and Empirical Examination. Journal of Marketing 62(4):13-29.

Li, T., Nicholls, J.A.F., and Roslow, S. (1999). The Relationships between Market-Driven Learning and New Product Success in Export Markets. International Marketing Review 16(6):47-50.

Mahoney, J.T. and Pandian, J.R. (1992). The Resource-Based View within the Conversation of Strategic Management. Strategic Management Journal 14(5):179-191.

Maltz, E. and Kohli, A.K. (1996). Market Intelligence Dissemination across Functional Boundaries. Journal of Marketing Research 33(1):46-61.
Matsuno, K., Mentzer, J.T., and Ozsomer, A. (2002). The Effects of Entrepreneurial Proclivity and Market Orientation on Business Performance. Journal of Marketing 66(3):18-32.

Meyers, P.W., Sivakumar, K., and Nakata, C. (1999). Implementation of Industrial Process Innovations. Journal of Product Innovation Management 16(3):295-311.

Mites, R. and Snow, C. (1978). Organizational Strategy, Structure and Process. New York: McGraw-Hill.

Miles, R.E., Snow, C.C., Meyer, A.D., and Coleman, H.J. Jr. (1978). Organizational Strategy, Structure, and Process. Academy of Management Review 3(3):546-562.

Miller, D. (1983). The Correlates of Entrepreneurship in Three Types of Firms. Management Science 29(7):770-791.

Miller, D. (1987). Strategy Making and Structure: Analysis and Implications for Performance. Academy of Management Journal 30(1):7-32.

Miller, D. and Droge, C. (1986). Psychological and Traditional Determinants of Structure. Administrative Science Quarterly 31(4):536560 .

Miller, D., Droge, C., and Toulouse, J.M. (1988). Strategic Process and Content as Mediators between Organizational Context and Structure. Academy of Management Journal 31(3):544-569.

Miller, D. and Friesen, P.H. (1978). Archetypes of Strategy Formulation. Management Science 24(9):921-933.

Miller, D. and Friesen, P.H. (1982). Innovation in Conservative and Entrepreneurial Firms. Strategic Management Journal 3(1):1-25.

Montoya-Weiss, M.M. and Calantone, R. (1994). Determinants of New Product Performance: A Review and Meta-Analysis. Journal of Product Innovation Management 11(5):1-20.

Moorman, C. (1995). Organizational Market Information Processes: Cultural Antecedents and New Product Outcomes. Journal of Marketing Research 32(3):318-335.

Moorman, C. and Miner, A.S. (1997). The Impact of Organizational Memory on New Product Performance and Creativity. Journal of Marketing Research 34(1):91-106.

Mullins, J.W. and Sutherland, D.J. (1998). New Product Development in Rapidly Changing Markets: An Exploratory Study. Journal of Product Innovation Management 15(3):224-236.

Narver, J.C. and Slater, S.F. (1990). The Effect of a Market Orientation on Business Profitability. Journal of Marketing 54(4): 20-35.

Noble, C.H., Sinha, R.K., and Kumar, A. (2002). Market Orientation and Alternative Strategic Orientations: A Longitudinal Assessment of Performance Implications. Journal of Marketing 66(4):25-39.

Nunnally, J. (1978). Psychometric Theory. New York: McGraw-Hill.

Olson, E.M., Walker, J.O.C., and Ruekert, R.W. (1995). Organizing for Effective New Product Development: The Moderating Role of Product Innovativeness. Journal of Marketing 59(1):48-62.

Ottum, B.D. and Moore, W.L. (1997). The Role of Market Information in New Product Success/Failure. Journal of Product Innovation Management 14(4):258-273.

Ozsomer, A., Calantone, R., and Di Benedetto, C.A. (1997). What Makes Firms More Innovative? A Look at Organizational and Environmental Factors. Journal of Business and Industrial Marketing 12(6):400-416.

Peteraf, M. (1993). The Cornerstones of Competitive Advantage: A Resource-Based View. Strategic Management Journal 14(3):179191.

Porter, M.E. (1981). The Contributions of Industrial Organization to Strategic Management. Academy of Management Review 6(4):609620 .

Rindfleisch, A. and Moorman, C. (2001). The Acquisition and Utilization of Information in New Product Alliances: A Strength-ofTies Perspective. Journal of Marketing 65(2):1-18. 
Sinkula, J.M. (1994). Market Information Processing and Organizational Learning. Journal of Marketing 58(1):35-45.

Slater, S.F. and Narver, J.C. (1995). Market Orientation and the Learning Orientation. Journal of Marketing 59(3):63-74.

Song, X.M. and Montoya-Weiss, M.M. (1998). Critical Development Activities for Really New versus Incremental Products. Journal of Product Innovation Management 15(2):124-135.

Song, X.M., Montoya-Weiss, M.M., and Schmidt, J.B. (1997). Antecedents and Consequences of Cross-Functional Cooperation: A Comparison of R\&D, Manufacturing, and Marketing Perspectives. Journal of Product Innovation Management 14(1):35-47.

Song, X.M. and Parry, M.E. (1996). What Separates Japanese New Product Winners from Losers. Journal of Product Innovation Management 13(5):422-439.

Song, X.M. and Parry, M.E. (1997). The Determinants of Japanese New Product Successes. Journal of Marketing Research 34(1):64-76.

Song, X.M., Thieme, R.J., and Xie, J. (1998). The Impact of CrossFunctional Joint Involvement across Product Development Stages: An Exploratory Study. Journal of Product Innovation Management 15(4):289-303.
Souder, W.E., Sherman, J.D., and Davies-Cooper, R. (1998). Environmental Uncertainty, Organizational Integration, and New Product Development Effectiveness: A Test of Contingency. Journal of Product Innovation Management 15(6):520-533.

Souder, W.E. and Song, X.M. (1997). Contingent Product Design and Marketing Strategies Influencing New Product Success and Failure in US and Japanese Electronics Firms. Journal of Product Innovation Management 14(1):21-34.

Souder, W.E. and Song, X.M. (1998). Analyses of US and Japanese Management Processes Associated with New Product Success and Failure in High and Low Familiarity Markets. Journal of Product Innovation Management 15(3):208-223.

Tatikonda, M.V. (1999). An Empirical Study of Platform and Derivative Product Development Projects. Journal of Product Innovation Management 16(1):3-26.

Utterback, J.M. and Abernathy, W.J. (1975). A Dynamic Model of Product and Process Innovation. Omega 3(6):639-656.

Workman, J.P. Jr. (1993). Marketing's Limited Role in New Product Development in One Computer Systems Firm. Journal of Marketing Research 30(4):405-421. 
Table A1 Appendix. Measures, Reliabilities, and Confirmatory Factor Analysis Factor Loadings

ENVIRONMENTAL TURBULENCE (7-point semantic differential scale): $\alpha=.775$; composite reliability $=.795$

1. Actions of competitors are quite easy to predict (as in some primary industries).

2. Demand and consumer tastes are fairly easy to forecast.

3. The production/service technology is not subject to very much change and is well

$\ldots \ldots \ldots \ldots \ldots$ Actions of competitors are unpredictable.

$(\lambda=.674)$ established.

PROACTIVE STRATEGIC ORIENTATION (7-point semantic differential scale): $\alpha=.874$; composite reliability $=.875$

1. In dealing with its competitors, the firm Resorts much more to a live and let live $\ldots \ldots \ldots \ldots \ldots$ Demand and tastes are almost unpredictable. $(\lambda=.778)$ philosophy

2. In general, the top managers of my firm believe that ...

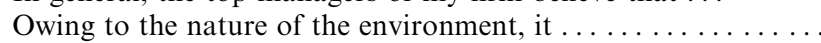
is best to explore it gradually via timid, incremental behavior.

The modes of production/service change often $(\lambda=.767)$ and in a major way.

3. When confronted with decision-making situations involving uncertainty, my firm ...

Typically adopts a cautious, "wait-andsee" posture to minimize the probability of making costly decisions.

Has become more aggressive.

ORGANIZATIONAL STRUCTURE (7-point semantic differential scale): $\alpha=.875$; composite reliability $=.877$

$\ldots \ldots \ldots \ldots \ldots$

Typically adopts a bold, aggressive posture to maximize the probability of exploiting potential opportunities. In general, the operating management philosophy in my firm favors ...

1. Highly structured channels of $\ldots \ldots \ldots \ldots \ldots$ Open channels of communication with communication and a highly restricted important financial and operating information access to important financial and operating information.

2. A strong insistence on uniform managerial style throughout the firm.

3. A strong emphasis on always getting personnel to follow the formally laid procedures.

INNOVATIVENESS (7-point semantic differential scale): $\alpha=.830$; composite reliability $=.835$ In general, the top managers of my firm favor ...

1. A strong emphasis on the marketing of flowing quite freely throughout the organization. Managers' operating styles allowed to range $(\lambda=.835)$ freely from the very formal to informal A strong emphasis on getting things done even $(\lambda=.798)$ if this means disregarding formal procedures. tried and the true products or services.

2. How many lines of products or services has your firm marketed in the past five years? No new lines of products or services. Changes in product or service lines have $\ldots \ldots \ldots \ldots \ldots$ Very many new lines of products or services

been mostly of a minor nature.

\section{Changes in product or service lines have} usually been quite dramatic.

$$
(\lambda=.820)
$$

$\ldots \ldots \ldots \ldots \ldots$

agree and 0 is strongly disagree): $\alpha=.856$; composite

\section{reliability $=.893$}

Please rate your latest new product project, relative to your direct competitors in your industry.

1. Preliminary market assessment was done.

2. Overall we had superior intelligence on our competitors.

3. Overall we had superior intelligence on our customers.

NEW PRODUCT SUCCESS (11 point scales): $\alpha=.751$; composite reliability $=.761$

1. Please rate the degree to which this product was a success or failure from a profitability standpoint.

A great financial failure; far short of our minimum profitability criteria

$\begin{array}{llllll}-5 & -4 & -3 & -2 & -1 & 0\end{array}$
A borderline case: barely met minimum profitability criteria
A great financial success; far exceeded our minimum profitability criteria

2. How would you rate the overall financial (profitability) success of your firm's new product development program over the last five years?

$\begin{array}{lllllllllllll}\text { Very unsuccessful } & -5 & -4 & -3 & -2 & -1 & 0 & 1 & 2 & 3 & 4 & 5 & \text { Very successful }\end{array}$ 